ks. Libero Gerosa

Facoltà di Teologia di Lugano

DOI: $10.15290 /$ std.2018.04.12

\title{
WYZWANIE ZAKORZENIONE W DOŚWIADCZENIU EDUKACYJNYM MŁODZIEŻY KAROLA WOJTYŁY I LUIGIEGO GIUSSANIEGO
}

\section{A CHALLENGE ROOTED IN THE EDUCATIONAL EXPERIENCE OF THE YOUNG PERSON OF KAROL WOJTYŁA AND LUIGI GIUSSANI}

The human person is subjected to the process of upbringing and formation. The family, school and church play an important role in this process. The author concentrates on education and youth education in the interpretation of Karol Wojtyla and Luigi Giussani. He explores a fragmentary problem with regard to the understanding of the vocation to the priesthood. It is important that during this process, the youth confronts the imperishable truth that fits into the meaning of human existence and not only the temporal categories of life that are piecemeal to some planes. The educators play an important role, and they should have a mature, integrated personality.

Key words: Wojtyła, Giussani, a human person, vocation, education, formation, youth.

Wprowadzenie: pytania postawione przez znaki czasu

Synod Biskupów z jesieni 2018 roku nosi tytuł „Młodzież, wiara i rozeznanie powołania”, co sugeruje, że „Kościół katolicki zdecydował - jak stwierdzono w dokumencie przygotowawczym - postawić pytanie w jaki sposób towarzyszyć 
młodym ludziom w rozeznaniu i przyjęciu wezwania do miłości i życia w pełni” (Wprowadzenie, par. 2).

Wezwanie to nie tylko przywołuje pewną liczbę kobiet i mężczyzn, ale przede wszystkim młodość, która jest w sercu każdej osoby, niezależnie od wieku, i z tego powodu odpowiedź dzisiejszego Kościoła podobnie jak i dwa tysiące lat temu nie może być niczym innym - jak to podkreślał Papież Jan Paweł II w swoim pamiętnym liście Dilecti amici z 1985 roku zwracając się do młodych chłopców i dziewcząt z całego świata - jak „odpowiedzią, która dotyczy całego życia, która zamyka w sobie całokształt ludzkiej egzystencji”". W rzeczywistości, jeśli zrozumiemy, że „człowiek jest podstawową i zarazem codzienną drogą Kościoła” to możemy zrozumieć, dlaczego „Kościól przywiązuje szczególną wagę do okresu młodości jako kluczowego etapu życia każdego człowieka”. Już Ojcowie Soboru Watykańskiego II byli tego świadomi, gdy w Konstytucji duszpasterskiej Gaudium et spes stwierdzili: „Kościół zawsze ma obowiązek badać znaki czasów i wyjaśniać je w świetle Equangelii, tak aby mógł w sposób dostosowany do mentalności każdego pokolenia odpowiadać ludziom na ich odwieczne pytania dotyczące sensu życia obecnego" (GS 4).

Zasada ta jest podejmowana i stosowana z determinacją przez św. Jana Pawła II w jego adhortacji posynodalnej Pastores dabo vobis (25 marca 1992) w odniesieniu do formacji kapłanów $w^{3}$. Ale co to znaczy badać i interpretować znaki czasu w świetle Equangelii? Co dzisiaj oznacza ta hermeneutyczna potrzeba? Czy nadal ważna jest teza postawiona przez Jana Pawła II?

Zatem wśród najbardziej dramatycznych znaków na początku trzeciego tysiąclecia w zakresie edukacji do wiary chrześcijańskiej można wymienić następujące:

według Annuarium Statisticum Ecclesiae z 2015 roku, opublikowanym 6 kwietnia 2017 przez „Biuletyn Prasowy” Stolicy Apostolskiej, rok 2015 odznacza się spadkiem ogólnej liczby kapłanów w odniesieniu do roku poprzedniego, szczególnie odczuwanym na kontynencie europejskim (-2502 jednostek czyli -5,8\%!). Jeszcze bardziej niepokojącym zjawiskiem jest „spadek powołań kapłańskich”: z 99,5 seminarzystów na milion katolików w 2010 roku do 90,9 w 2015 roku a w Europie zanotowano spadek o 9,7\% w tym samym okresie! Jeśli na poziomie liczb absolutnych Kościół

1 Jan Paweł II, Lettera apostolica „Dilecti amici” per l'Anno internazionale della gioventù, 26 marca 1985, [w:] Insegnamenti di Giovanni Paolo II, t. VIII, 1 (Roma 1985), tekst łaciński s. $757-800$ i thum. wl. s. $801-837$, tu akapit 3, s. 805.

2 Ibidem, akapit 1, s. 801.

3 Por. Jan Pawel II, Esortazione Apostolica „Pastores dabo vobis”, nr 10, 25 marca 1992, [w:] AAS 84 (1992), s. 657-804; komentarz w perspektywie tego zagadnienia, por. L. Gerosa, Adduxit eum ad Iesum (J 1, 42). La formazione dei presbiteri o „pastori” secondo Giovanni Paolo II, [w:] Formare sacerdoti per il terzo millennio. Riflessioni a vent'anni dalla Pastores dabo vobis, M. Cardinali (red.), Città del Vaticano 2012, s. 49-70. 
w Polsce wciąż pozostaje, przynajmniej w Europie, najważniejszą kuźnią powołań prezbiterów, obecne trendy nie pozwalają w żaden sposób „spoczywać na laurach”; w rzeczywistości, jeśli pod pontyfikatem Jana Pawła II nastąpił maksymalny wzrost o około 33\% powołań kapłańskich, od 1992 do 2012 r., czyli w okresie silnego spadku liczby ludzi w Polsce w okresie 18-20 lat, nawet w polskich diecezjach liczba powołań kapłańskich znacznie się zmniejszyła, osiągając szczyt 45\% w Wyższych Seminariach Diecezjalnych, a nawet 67\% w zakonnych. Chociaż nie ma oficjalnych statystyk dotyczących liczby kapłanów, którzy opuścili stan kapłański i zawarli związki małżeńskie, z danych Watykanu wynika, że liczba takich przypadków nieznacznie wzrosła: w okresie tych pięciu lat, 0,26\% z wszystkich kapłanów (czyli 5383 kapłanów) opuściło stan kapłański z różnych przyczyn. Większość wniosków o zwolnienie ze stanu duchownego spowodowanych jest sytuacjami niestabilności emocjonalnej, choć zdarzają się przypadki kryzysu wiary lub też konfliktów z przełożonymi.

Nie mniej niepokojącym faktem dla każdej instytucji wychowawczej, a więc i dla Kościoła katolickiego, jest imponujący wzrost uzależnień cyfrowych dzisiejszych młodych ludzi, i to zaledwie dziesięć lat po tym, jak pojawił się pierwszy iPhone. Dowodem na to jest fakt, że w styczniu 2017 r. we Francji zatwierdzono prawo do odłaczenia oraz stopniowe rozpowszechnianie „digitaldetox.it” w celu przezwyciężenia poważnych szkód dla zdrowia fizycznego i psychicznego spowodowanych ciągłym „połączeniem” przez część nastolatków i młodych ludzi

W obliczu tych alarmujących znaków czasu, jak możemy wdrożyć ogólne wytyczne wychowawcze zawarte w Ratio Fundamentalis Institutionis Sacerdotalis $^{5}$, opublikowanym przez Kongregację ds. Duchowieństwa w dniu 8 grudnia 2016 roku? Czy te systematyczne sugestie dokonane w tym długim i szczegółowym, 180-stronicowym dokumencie, są naprawdę trwałe i ważne dla każdego kontynentu? W rzeczywistości, np.:

jak uzasadnić, pomimo alarmujących znaków, o których już wspomniano, usunięcie kwestii formacji ludzkiej nowych prezbiterów do rozdz. 5 (nr 93-100) i to po kolejnym nadaniu priorytetu tzw. niższym seminariom klasycznego typu? Z drugiej strony jest całkiem pewne, że przynajmniej w krajach uprzemysłowionych, powołania dorosłych nadal są uważane za wyjątki i dlatego czy tylko dla nich „należy przewidzieć okres duchowej i eklezjalnej drogi, w czasie której mogłoby się dokonać poważne rozeznanie ich motywacji powołaniowych" (nr 24)? Czy dorastający i młodzi ludzie w tych krajach nie potrzebują ,poważnego rozeznania” swojego powołania?

Jak uzasadnić wiarę w obecną sytuację, że wystarczy „przemyślenie” w kwestii w jaki sposób „formacja ludzka” nowych kapłanów może stanowić „niezbędny element ewangelizacji” pod warunkiem uznania „sieci społecznościowych” za

$4 \quad$ Por. L. Di Corcia, Liberi nella rete. Le dipendenze digitali, [w:] "Ticino" 7, nr 52, Lugano (CH) 29 grudnia 2017.

5 Por. Kongregacja do spraw Kleru, Il dono della vocazione presbiteriale. Ratio Fundamentalis Institutionis Sacerdotalis, Milano 2016. 
rodzaj „nowej agory”, czy też nowej „otwartej przestrzeni publicznej, w której ludzie dzielą się pomysłami, informacjami i opiniami”, poprzez które ich użycie wydaje się automatycznie za proste i techniczne rozwinięcie słów Jezusa: „Będziecie moimi świadkami... aż po krańce ziemi" (Dz 1,8)?

Czy te systematyczne i merytoryczne wybory są zgodne z nauczaniem soborowym? Czy są zgodne z ostatnim nauczaniem papieskim i zarazem z samym Synodem Biskupów z 1990 roku na temat „Formacja kapłanów we współczesnym świecie"? Czy rzeczywiście usprawiedliwiają one centralne znaczenie formacji ludzkiej w procesie wychowawczym młodych ludzi, a zwłaszcza nowych kapłanów?

Przedstawione tu dane statystyczne i zapytania z nich wynikające wzbudzane w tych, którzy są wezwani do dokładnego sprawdzania i interpretowania znaków czasu, zgodnie z Equangelią, nie pozostawiają wątpliwości: dzisiaj jest absolutnie konieczne, aby Kościół katolicki rozeznawał w nowy i głęboki sposób drogę powołania wewnątrz globalnego horyzontu formacji ludzkiej i kościelnego wychowania wszystkich młodych ludzi.

\section{Centralne miejsce formacji ludzkiej na drodze powołania młodzieży i nowych kapłanów}

W Orędziu Ojców Synodu do Ludu Bożego zatytułowanym Formacja kapłanów we wspótczesnym świecie (28 października 1990 r.) Ojcowie Synodalni stwierdzają: Przygotowując się do kapłaństwa, musimy też nauczyć się dawania osobistej odpowiedzi na podstawowe pytanie Chrystusa: „Czy miłujesz mnie?" (J 21, 15). Odpowiedzią przyszłego kapłana może być tylko całkowity dar własnego życia"

Właśnie dlatego, że jest przekonany o tej prawdzie, św. Jan Paweł II w swojej adhortacji posynodalnej Pastores dabo vobis (25 marca 1992) dokonuje dwóch fundamentalnych obserwacji; pierwsza dotyczy metody lub porządku systemowego: „Bez odpowiedniej formacji ludzkiej cała formacja kapłańska byłaby pozbawiona swego niezbędnego fundamentu” (nr 43); druga: „Kapłan winien kształtować swą ludzką osobowość w taki sposób, by stawać się dla innych pomostem, a nie przeszkodą w ich spotkaniu z Jezusem Chrystusem” (nr 43).

Konsekwencje wychowawcze na ścieżkach formacji chrześcijańskiej nowych pokoleń są liczne, także i przede wszystkim na drodze przygotowań nowych kapłanów. Tutaj, wymienione są tylko te, które na poziomie ogólnym, są dzisiaj najtrudniejsze do wdrożenia w poszczególnych Kościołach; na poziomie konkretnych doświadczeń tylko dwie z tych, które są najistotniejsze.

Rozdz. 4, akapit 3 cytowanego Orędzia, którego tekst oficjalny w języku łacińskim i tłumaczenie włoskie znajdują się w: EV, t. 12 (Bologna 1992), s. 430-443, tu s. 439. 


\section{Konsekwencje na poziomie ogólnych kryteriów wychowawczych}

Wychowawcze konsekwencje potwierdzonej centralności formacji ludzkiej na drodze powołania młodych ludzi są zasadniczo dwie. Oto one:

Po pierwsze, jeśli formacja ludzka nowych kapłanów ma zasadnicze znaczenie, to w tym kontekście musi dokonać się „doniosły i decydujący proces kształtowania u kandydata do kapłaństwa dojrzałości uczuciowej, będącej wynikiem wychowania do prawdziwej i odpowiedzialnej miłości”?

Innymi słowy, zamiast nadmiernego i błędnego zwrócenia uwagi po Soborze Watykańskim II, na tzw. kurs duszpasterski lub staż, ponieważ istotą posługi są słowa - „I przyprowadził go do Jezusa” (J 1,42) - jest jednoznaczne z ludzką dojrzałością kapłana - i absolutnie konieczne i właściwe, aby myśleć o „okresie propedeutycznym”, analogicznie do „nowicjatu” Instytutów życia konsekrowanego, aby zapewnić przełożonym i kandydatom odpowiedni czas i lepsze środowisko do rozeznawania powołania i zweryfikowania dojrzałości emocjonalnej koniecznej do realizacji trwałego „oddania”, zdefiniowanego przez Jana Pawła II jako fundament „stały i niezbędny dla miłości pasterskiej”.

Po drugie, aby ułatwić skuteczną integrację podstawowej formacji ludzkiej z pozostałymi trzema (tj: formacją duchową, formacją intelektualną i formacją duszpasterską) w „spójną drogę chrześcijańskiego i kapłańskiego życia”10, jest absolutnie konieczne przyjęcie dwóch bardziej ogólnych kryteriów wychowawczych podkreślonych przez Jana Pawła II: 1. wyobrażenie seminarium nie jako „materialnej przestrzeni” lub jakiegoś „miejsca”, ale jako „środowiska sprzyjającego procesowi formacyjnemu" ${ }^{11}$; 2. analogicznie, gdy chodzi o powołania dojrzałe poprzez rozwój „w specyficznym procesie formacji powołaniowej”12, jak również poprzez pielęgnację „kapłańskich ziaren powołania”, zasianych przez Boga „w sercach dzieci” i młodzieży ${ }^{13}$, nie zawsze jest możliwe, aby myśleć o „niższym seminarium” w klasycznym sensie, ale raczej „trzeba stworzyć inne „instytucje”, jak chociażby grupy powołaniowe dla chłopców i młodzieży”14.

W Kościołach partykularnych nie brakuje znaczących przykładów realizacji tych zasad i kryteriów wychowawczych, zdolnych do promowania fascynacji

\footnotetext{
$7 \quad$ Jan Paweł II, EA Pastores dabo vobis, n. 43.

8 Ibidem, n. 62.

9 Ibidem, n. 23.

$10 \quad$ Ibidem, n. 42.

11 Ibidem, n. 42, akapit 2.

12 Ibidem, n. 64, akapit 2.

13 Ibidem, n. 63.

14 Ibidem, n. 64, akapit 1.
} 
powołaniem kapłańskim w nowy sposób: od nowych szkół katolickich utworzonych po Vaticanum II do bardziej konkretnych doświadczeń, takich jak ten o nazwie „Sykomora. Projekt, który rośnie”. Ten ostatni polega na proponowaniu życia wspólnotowego ukierunkowanego na rozeznanie powołania dla uczniów szkól średnich „pragnących pogłębić swoją przyjaźń z Jezusem i poszukujących, jak spędzić z Nim życie. Przez tydzień w miesiącu, bez zaniedbywania lekcji i dodatkowych zajęć, ci młodzi ludzie żyją wspólnie pod okiem kapłana i małżeństwa, którzy wraz z nimi mieszkają" ${ }^{15}$. Inne podobne doświadczenia zostały ostatnio opisane przez „Rivista del Clero Italiano”.

W tym miejscu chcielibyśmy pokrótce opisać tylko dwa świadectwa narodzone w przededniu Soboru Watykańskiego II, a jednocześnie tak powszechne, że możemy wciąż dzisiaj proponować nowe, może nawet bardziej skuteczne, formy realizacji soborowego duszpasterstwa powołaniowego.

\section{Emblematyczne doświadczenia duszpasterstwa powołaniowego}

\section{Świadectwo wychowawcy Karola Wojtyły}

Powszechnie uznaje się, że św. Jan Paweł II we wszystkich etapach życia był wielkim wychowawcą młodzieży i fascynującym inicjatorem chrześcijańskich powołań. Nie ulega też wątpliwości, że przyjaźń zawsze była podstawowym wymiarem jego działalności duszpasterskiej, o czym świadczy jego niezwykła „odpowiedzialność w kultywowaniu więzi z wiernością"17.

Wytyczne wychowawcze tej wielkiej aktywności jako formatora młodych studentów, chłopców i dziewcząt sięgają wiosny 1948 roku, kiedy to utworzył sieć przyjaźni zwanych „Środowisko”, która rozwinęła się wokół Księdza Karola, zwanego rodzinnie „Wujek”. Była to absolutnie nowatorska propozycja wychowawcza, jeśli tylko weźmie się pod uwagę, że w tamtym czasie tzw. koedukacja spotykała się z wieloma podejrzeniami hierarchii katolickiej. Wtedy właśnie w „Środowisku” u Księdza Karola dojrzewają te zasady, które później jako arcybiskup krakowski, jeszcze przed Soborem Watykańskim II, zgromadzi w podstawowym dziele Miłość i odpowiedzialność (Lublin 1960), opublikowanym po raz pierwszy w języku włoskim w Turynie w 1969 roku.

\footnotetext{
15 AA.VV., Il Sicomoro. Un progetto che cresce, Como 2017, s. 3 (por. też sicomoro@diocesidicomo.it).

16 Por. „Rivista del Clero Italiano”, XCV, 2014, s. 791-880.

17 A. Riccardi, Giovanni Paolo II. La Biografia, Cinisello Balsamo 2011, s. 81.
} 
W dziele tym głównym tematem jest powołanie, nawet jeśli podtytuł brzmi: Studium etyczne ${ }^{18}$.

Dla Wojtyły powotanie, nawet jeśli w świeckiej kulturze przedsoborowej termin ten jest nadal używany w znaczeniu administracyjnym wezwania do służby lub zadania, jest decydującym momentem w rozwoju całej osoby ludzkiej, każdej osoby ludzkiej, zdolnym do ukierunkowania całego życia. To „odkrycie orientacji w możliwościach działania i odpowiednie zaangażowanie stanowią jeden $z$ najbardziej decydujących momentów dla formowania osobowości, dla wewnętrznego życia człowieka" ${ }^{19}$. Z tych powodów w refleksjach Księdza Karola „powołanie jest zawsze główną orientacją ludzkiej miłości. Oznacza nie tylko miłość, ale dar z siebie czyniony z miłości”20.

W takiej definicji nie ma miejsca na jakąkolwiek formę „spirytualizmu” czy „klerykalizmu”, i to do tego stopnia, że Wojtyła potwierdza, nawet przed Soborem Watykańskim II, i to w naprawdę dalekowzroczny sposób, że „zarówno dziewictwo jak i matżenstwo, rozumiane w ich głęboko personalistycznym znaczeniu, są powołaniami”. Każde z nich to „świadomy wybór dokonany przez osobę"21, który określa „orientację jego życia i jego działania”. Ten stan (małżeństwo czy celibat), który po nich następuje „ma tu tylko funkcję drugorzędną”22 i jest zasadniczo konsekwencją - jak to określi już jako Papież! - „młodości” jako „czasu szczególnie intensywnego odkrycia ludzkiego ego oraz właściwości i możliwości z nim związanych" ${ }^{23}$. Jest to odkrycie związane z konkretnym, osobistym, głębokim doświadczeniem spojrzenia miłości, które Jezus skierował do młodzieńca, o którym mowa w Ewangeliach ${ }^{24}$. Spojrzenie, które wzbudza w sercu każdego mężczyzny i każdej kobiety pragnienie „więcej”; ponaglany tym spojrzeniem „człowiek jest prowadzony wewnętrznie, dzięki pomocy Ducha Świętego, z życia zgodnego z przykazaniami do życia w świadomości daru, a spojrzenie pełne miłości Chrystusa wyraża to wewnętrzne przejście ... Człowiek (staje się w ten sposób) ... zdolnym do życia w wymiarze daru”25, nawet jeśli oznacza to „podążanie wbrew utartym prądom krążących opinii

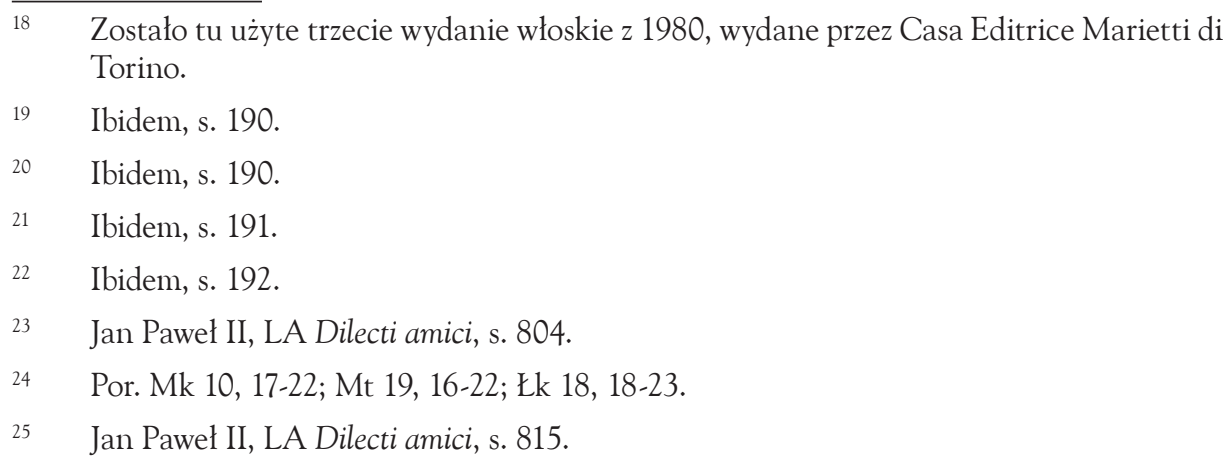


i propagandowych haseł!”26, a zatem implikuje zarówno lęk przed „miłością, która stawia wymagania człowiekowi”27 jak też zdolność do rozeznawania, w zakresie wszystkiego, co ludzkie"28.

Podsumowując: wszystkie podstawowe cechy jego doświadczeń wychowawczych prowadzą do wniosku, że dla Księdza Wojtyły „formacja ludzka” ma zasadnicze znaczenie dla tworzenia tożsamości i osobowości każdego człowieka, i jako taka jest w centrum każdego procesu formacyjnego, a zwłaszcza $\mathrm{w}$ dotyczącym nowych prezbiterów ${ }^{29}$. W rzeczywistości formacja ludzka jest nie tylko ostatecznie zakorzeniona w tajemnicy Słowa Wcielonego, ale jest to perspektywa, którą Ewangelia ukazuje jako największą „Uczynię was rybakami ludzi" (Mt 4,19). Zatem dla wychowawcy i formatora, Księdza Karola, jak to wytłumaczy już jako Papieża w swojej książce Pamięć i tożsamość (Mediolan 2005), autentyczna antropologia zawsze była zakorzeniona w chrystologii. Stwierdzenie Soboru Watykańskiego II, iż „Tajemnica człowieka wyjaśnia się naprawdę dopiero w tajemnicy Słowa Wcielonego" (GS 22), oznacza, że nawet na poziomie wychowania i formowania człowiek ,jest pierwszą i podstawową drogą Kościoła, drogą wyznaczoną przez samego Chrystusa" ${ }^{\text {”o }}$.

\section{Świadectwo wychowawcy ks. Luigiego Giussaniego}

Nie ma wątpliwości, że ks. Luigi Giussani (1922-2005) także był wielkim wychowawcą. Świadczą o tym przede wszystkim następujące fakty: był założycielem ruchu „Komunia i Wyzwolenie”, ruchu kościelnego rozsianego po całym świecie, z którego szeregów wyszło wielu młodych kapłanów, ale również wielu młodych mężczyzn i kobiet, członków tradycyjnych wspólnot zakonnych oraz członków wspólnoty świeckich konsekrowanych „Memores Domini” zatwierdzonej 8 grudnia 1988 r. przez Papieską Radę ds. Swieckich ${ }^{31}$. Posiadał sprecyzowane zamiary wychowawcze: „Chrześcijaństwo staje się sympatyczne poprzez to, iż zostaje odkryte jak najlepsza hipoteza w kontekście czynników ludzkich. Ze swej natury jest ideałem służącym formowaniu młodych ludzi”32.

\footnotetext{
$26 \quad$ Ibidem, s. 822 .

27 Ibidem, s. 822.

28 Ibidem, s. 831.

29 W związku z tym por. K. Wojtyła, Experiences de nos grands séminaires: l'obéissance et l'esprit de dépendance, "Seminarium" n. 1 (1969), s. 79-87 i idem, La sainteté sacerdotale comme carte d'identité, "Seminarium" n. 1 (1978), s. 167-181.

30 Jan Paweł II, Encyklika Redemptor hominis (4 marca 1979), cytowana tu za: Jan Paweł II, Tutte le encicliche, red. R. Fisichella, Varese 2010, n. 14, s. 145.

31 Papieska Rada do spraw świeckich, Decreto di riconoscimento della "Memores Domini", [w:] EV, Vol. 11 (Bologna 1991), ss. 1014-1016.

32 L. Giussani, Realtà e giovinezza. La sfida, Milano 2018, Premessa (luty 1995), s. X.
} 
Doczekał się niezliczonych i wiarygodnych świadectw. W szczególności, w swojej depeszy kondolencyjnej po śmierci ks. Luigiego Giussaniego (22 lutego 2005 r.) Jan Paweł II podkreślił: „Całą jego działalność duszpasterską można podsumować w braterskim i zdecydowanym zaproszeniu, poprzez które umiał się zwrócić do tych, którzy go przybliżali do osobistego spotkania z Chrystusem, do petnych $i$ definitywnych odpowiedzi na najgłęsze oczekiwania ludzkiego serca"33.

$\mathrm{Z}$ tego powodu wielu młodych ludzi, obecnie dorosłych, uważało go za swego „duchowego ojca”, podkreśla Jan Paweł II $^{34}$. Ale jakie są najgłębsze podstawy tego doświadczenia wychowawczego? Jakie są jego główne cechy metodologiczne?

Od lat pięćdziesiątych (tak, jak w przypadku Jana Pawła II, w przededniu Soboru Watykańskiego II) ks. Luigi Giussani był przekonany, że „aby spotkać Chrystusa... musimy najpierw poważnie ustawić nasz ludzki problem" ${ }^{35}$. Tak, jak u pierwszych uczniów Jezusa (zob. J 1,35 i nast.) również dzisiaj: „Chrystus przychodzi tutaj, do mojego zachowania się jako człowieka, tego, który na coś czeka, ponieważ uznaje swoje niedoskonałości; staje wraz ze mną, postanawia

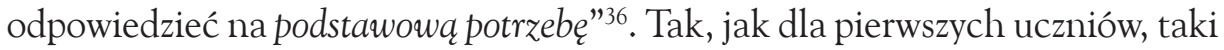
i dla dzisiejszej młodzieży, upewnienie się, że Jezus Chrystus jest prawdziwą odpowiedzią na „podstawowe potrzeby” każdego człowieka zawsze zakłada, w mniemaniu wychowawcy ks. Giussaniego, zaangażowanie własnego „ja”, tak głęboko, „aby usłyszeć braterską solidarność z „ja” każdego innego człowieka”37; oznacza zawsze to dzielenie się własnym doświadczeniem $z$,wspólnotą, która ma być akceptowana lojalnie i intensywnie" ${ }^{38}$. Innymi słowy, jeśli chcesz naprawdę „żyć inteligentnie” droga wychowania proponowana przez formatora lub wychowawcę, musi być długa i męcząca, podobna do drogi Apostołów, którzy poszli za Jezusem niewiele rozumiejąc, ale czuli jednoznacznie, że Jezus stał się ich „centrum emocjonalnym” 39 , będąc ,jedynym, w którego słowach wszystkie ludzkie doświadczenia zostaty zrozumiane, a ich potrzeby potraktowane poważnie i ujawnione tam, gdzie były nieświadome i zdezorientowane" ${ }^{\text {" }}$.

33 Jan Paweł II, Lettera per la morte di Mons. Giussani, [w:] EV, Vol. 23 (Bologna 2008), s. 291-293, tu akapit 2, s. 292.

34 Ibidem, akapit 3, s. 292.

35 L. Giussani, Tracce d'esperienza cristiana, [w:] L. Giussani, Il cammino al vero è un'esperienza, Milano 2016, s. 84.

36 Ibidem, s. 84.

37 Ibidem, s. 87.

38 L. Giussani, Il rischio educativo, Milano 1977, s. 44.

39 L. Giussani, Tracce d'esperienza cristiana, s. 83.

$40 \quad$ Ibidem, s. 83. 
Zaczynając od wewnętrznego związku między tym „centrum emocjonalnym”, zajmowanym przez Jezusa Chrystusa jako prawdziwa odpowiedź na „pierwotną potrzebę" każdego człowieka. Ksiądz Giussani buduje swoją wychowawczą propozycję dla młodych ludzi w drodze do ich powołania i realizacji ich człowieczeństwa. Jest to jednak wyzwanie i ryzyko, podejmowane przy pomocy precyzyjnej metody pedagogicznej i mające swój punkt centralny w „pewności istnienia sensu rzeczy”41. Jest to „przyjazna metoda” wprowadzenia młodego człowieka w „totalną rzeczywistość”, a zatem ukierunkowanie go na jego własną „ludzką dojrzałość”. Metoda pedagogiczna, jak stwierdził ks. Giussani, komentując list Dilecti amici Jana Pawła II, nierozwinięta w prawdziwym „zestawieniu ale, jeśli, może, by ochronić od odwrócenia się w zaangażowaniu w rzeczywistość"42; metoda pedagogiczna nieukierunkowana na wątpliwości które zastępują podstawowe pytania dotyczące sensu życia i rzeczywistości ${ }^{43}$. Metoda pedagogiczna ks. Giussaniego rozwija się w horyzoncie teologiczno-filozoficznej wizji rzeczywistości, podsumowanej w stwierdzeniu św. Tomasza z Akwinu: „Istnienie jest tam, gdzie działanie!”44 Są zatem niezaprzeczalne analogie do metody wychowawczej Wojtyły; ale jakie są główne źródła metody wychowawczej ks. Giussaniego?

Powracając do definicji wychowania jako „wprowadzenia do rzeczywistości”, opracowanego przez niemieckiego jezuitę Jungmanna ${ }^{45}$, ks. Giussani stosuje ją z ojcostwem i rygorem w swojej ogromnej pracy z młodymi ludźmi, pragnąc otworzyć ich serca na całość rzeczywistości. Dla niego ścieżka wychowawcza to ,... rozwój wszystkich struktur jednostki, aż do ich integralnej realizacji, a jednocześnie afirmacja wszystkich możliwości aktywnego połączenia tych struktur z całością rzeczywistości”"46.

Podsumowując należy zauważyć, używając sformułowania ks. Giussaniego, że orientacja lub droga wychowawcza młodzieży:

Musi przede wszystkim otworzyć ich na samych siebie, to znaczy głęboko docenić ich doświadczenia, spojrzeć ze współczuciem na człowieka ukrytego w nich; musi

\footnotetext{
$41 \quad$ L. Giussani, Il rischio educativo, s. 21.

42 L. Giussani, Realtà e giovinezza. La sfida, s. 7.

43 Por. ibidem, s. 22.

44 Por. Tommaso D’Aquino, Quaestiones disputatae, "De veritate”, q. 10, art. 8, c; cytat za: L. Giussani, Realtà e giovinezza. La sfida, s. 22.

45 Cfr. J.A. Jungmann, Christus als Mittelpunkt religiöser Erziehung, Friburg i. Br. 1939, s. 20.

46 Cytat genialnego dzieła Il rischio educativo zaczerpnięty z wydania z 2005 (Rizzoli) ze znaczącym podtytułem: Il rischio educativo. Come creazione di personalità e storia, tu s. 65; cfr. komentarz: M. Camisasca, Don Giussani. La sua esperienza dell'uomo e di Dio, Cinisello Balsamo 2009, s. 40.
} 
wziąć pod uwagę to, kim naprawdę są. Szanować oznacza traktować poważnie to, co czują, wszystko... ${ }^{47}$

To „ukierunkowanie na wszystko” w wychowaniu młodzieży rodzi dojrzałe i trwałe owoce tylko wtedy, gdy prowadzi do „... coraz większej autonomii wychowanka w osądzaniu rzeczywistości, która go otacza, dostarczając narzędzi do jego racjonalnego działania"; jest to możliwe

... tylko w całym zaangażowaniu nas samych i naszego życia we wspólnocie Kościoła, w tę tajemnicę Boga w świecie, w nieustannym pogotowiu, nieprzemijającej propozycji Chrystusa na przestrzeni wieków... (która implikuje) ... ciągłą poważną konfrontację ... i odpowiednią ocenę tradycji, z której się wywodzimy ${ }^{48}$.

\section{Formacja ludzka: wspólny mianownik dwóch opisanych propozycji wychowawczych}

Harmonia między propozycją wychowawczą ks. Giussaniego a tą, która została rozwinięta w tym samym czasie, tysiące kilometrów dalej, przez ks. Wojtyłę, jest naprawdę imponująca i „opatrznościowa” dla Kościoła trzeciego tysiąclecia.

Zatem:

- Przede wszystkim istnieje głęboka analogia między przekonaniem tego, zgodnie z którym edukacja „polega na wprowadzaniu młodych ludzi w totalną rzeczywistość ... (aby), poprzez ścieranie się z rzeczywistością i możliwość przyznania jej wolnego osądu, uczeń mógł spotkać się z Tajemnicą, która w całości odpowiada na jego pytania" i młodym wykładowcą z Uniwersytetu Lubelskiego, który później został papieżem, według którego uniwersytet jest „miejscem naukowej prawdy, ale także prawdy życiowej”, ponieważ ze swej natury miejsce to jest „szczególnym środowiskiem ukierunkowanym na znajomość całości"49.

- Po drugie, obaj sa zakochani w wolności wychowanego, nie abstrakcyjnie, ale w sposób konkretny i odpowiedzialny, ojcowski, ponieważ obaj są przekonani, że wychowawca jako taki, jest świadkiem, czyli „ekspertem”, który nie przekazuje siebie samego, ale odnosi się do prawdy, która jest przed nim $^{50}$. Co więcej, dla obu „mistrz-świadek” jest tym, który dyskretnie

47 L. Giussani, Tracce d'esperienza cristiana, [w:] Il cammino al vero, s. 84; w odniesieniu do tego „ukierunkowania na wszystko” formacji młodzieży imponująca jest zgodność z Janem Pawłem II; por. Jan Paweł II, Omelia del 9 giugno 1987 all'Università Cattolica di Lublino, Nr 2, [w:] Insegnamenti, Città del Vaticano 1987, Vol. X, 2, s. 2064-2072.

L. Giussani, Il rischio educativo, s. 75.

Por. Jan Paweł II, Omelia del 9 giugno 1987 all'Università di Lublino, [w:] Insegnamenti, Città del Vaticano 1987, t. X, 2, s. 2064-2072.

Dowodzi tego głęboka harmonia zarówno w sposobie rozważania ważności „sztuki towarzyszenia”, jak i „kierownika duchowego”, harmonia oparta na znajomości tradycji 
ks. Libero Gerosa, Wyzwanie zakorzenione w doświadczeniu edukacyjnym młodzieży...

wycofuje się za dominującą postać Jedynej Prawdy, którą się inspiruje; jego nauczanie i jego dyrektywa stanowią dar świadectwa i z tego właśnie powodu wpisuje się w pamięć ucznia z żywą i szczerą sympatią, niezależnie - w jego najgłębszym stopniu - od jego cech własnych. $\mathrm{Z}$ tego powodu więc wynika wdzięczność i niewymuszona więź z nauczycielem, a także przekonanie niezależne od niego ${ }^{51}$.

- Po trzecie, dla obu:

W Kościele najpełniej realizuje się metoda wychowawcza opisana powyżej: to przede wszystkim w niej młody człowiek znajduje tę hipotezę całkowitego poczucia rzeczywistości, która wywodzi się z tradycji świeckiej (depositum fidei) i która staje się kryterium, dzięki któremu z całą pewnością może osądzić świat; ponadto w Kościele wychowywany znajduje autorytet, który sprawia, że wzrasta i który, dzięki swojej konsekwencji, pozwala mu zrozumieć, że hipoteza jest możliwa do zrealizowania. Wspólnota kościelna daje młodym możliwość weryfikacji hipotezy w konkretnym doświadczeniu, aby można było się przekonać, że to, co otrzymali, jest prawdziwe ${ }^{52}$.

- W końcu, a jest to aspekt kluczowy, pomiędzy metodą wychowawczą ks. Giussaniego i ks. Wojtyły istnieje wspólny mianownik absolutnego znaczenia formacji ludzkiej, jak i jej głębokiej koniugacji z formacją duchową, nowych kapłanów. Ten wspólny mianownik jest głęboko zakorzeniony w tradycji karmelitańskiej, „Kierownika duchowego”, ze względu na niezaprzeczalną harmonię między obu "nauczycielami-świadkami” Giussanim i Wojtyłą oraz niezapomnianego nauczania „Mistrza wiary”, św. Jana od Krzyża:

Kierownikowi duchowemu - mówi mistyczny doktor - oprócz wiedzy i roztropności potrzeba jeszcze doświadczenia. Chociaż bowiem fundamentem dla prowadzenia duszy jest wiedza i roztropność, to jednak gdy przewodnikowi duchowemu brakuje doświadczenia w rzeczach czysto duchowych, nie potrafi prowadzić duszy, której się Bóg oddaje, gdyż nie potrafi tego zrozumieć ${ }^{53}$.

karmelitańskiej, por. przypis 52.

L. Giussani, Il rischio educativo, s. 107.

M. Campagnaro, La trasmissione della fede in una società secolarizzata sulla base degli scritti di Luigi Giussani, Varsavia 2016, s. 253.

53 Św. Jan od Krzyża, Żywy ptomień miłości, 3,30, [w:] Dzieła, Kraków, 1998, s. 770. Komentarz prawny, por. L. Gerosa, Dove nasce l'uomo vero? Per un esercizio autentico della Misericordia, Lugano - Siena 2016, s. 71-89, zwłaszcza przypis 31. 


\section{Pilna potrzeba uproszczenia, rozróżnienia i aktualizacji obecnych norm kanonicznych}

Kodeks Prawa Kanonicznego z 1983 używa tylko raz określenia „ludzka dojrzałość", w kan. 244 w odniesieniu do harmonijnej koordynacji formacji duchowej i intelektualnej seminarzystów oraz „zdolności ludzkich i moralnych” w zakresie przyjęcia do seminarium. Jest to jedyny wyjątek pośród ponad 30 długich i szczegółowych kanonów dotyczących „formacji duchownych”, którym poświęcony jest cały pierwszy rozdział III tytułu Święci szafarze księgi II KPK „Lud Boży”. Można się zastanawiać, czy po opublikowaniu Pastores dabo vobis (1992) Jana Pawła II podobne podejście do tego sektora kanonicznego ustawodawstwa nadal da się utrzymać.

Istnieje wiele powodów, które sugerują calkowita i głęboka rewizję. Oto niektóre z głównych, podkreślone przez doświadczenia wychowawcze opisane powyżej.

Przede wszystkim, właśnie dlatego, że dzisiaj nie każda diecezja jest w stanie zagwarantować istnienie i godne funkcjonowanie wyższego seminarium (zob. kan. 237 §1), należy poważnie rozważyć inne rodzaje rozwiązań (seminarium międzydiecezjalne, seminarium prowincjalne lub inne struktury) i taką decyzję należy pozostawić Konferencjom Episkopatów (patrz kan. 237 §1). Oznacza to zdrowe upraszczanie norm kodeksowych, które powinny skupiać się jedynie na ogólnych zasadach, aby zagwarantować centralne miejsce formacji ludzkiej nowych kapłanów i jej harmonizację z pozostałymi trzema aspektami formacyjnymi: formacją duchową, formacją intelektualną i formacją pastoralną.

Dwa ostatnie aspekty formacji, a mianowicie formacja intelektualna i pastoralna, stanowią ostateczne powody sprawiedliwego rozróżnienia drogi formacyjnej w ramach „Communio Ecclesiarum”, co zresztą sugeruje zapis kanonu $242 \S 1$, aby na terytorium każdej Konferencji Episkopatu były „normy” w tej sprawie, wydane przez Konferencję, z uwzględnieniem przepisów państwowych, dotyczących instytucji akademickich znajdujących się na danym terytorium.

Biorąc pod uwagę to uproszczenie i rozróżnienie, nietrudno skupić się na głównych treściach i zasadach koniecznej aktualizacji bieżących norm prawnych. Wystarczy, że kierujemy się tym niedoścignionym kamieniem milowym, którym jest posynodalna adhortacja apostolska Pastores Dabo Vobis Jana Pawła II oraz następujący po niej dokument opublikowany w 2008 roku przez Kongregację Edukacji Katolickiej i zatytułowany: Wskazania dotyczace wykorzystania nauk psychologicznych w przyjmowaniu i formacji kandydatów do kapłaństwa ${ }^{54}$. 
Istnieją trzy podstawowe zasady określone w tym dokumencie dla każdej aktualizacji uniwersalnych i poszczególnych norm kanonicznych, w dziedzinie tak ważnej dla Kościoła katolickiego; oto one:

„Formacja ludzka” jest „fundamentem całej formacji” nowych kapłanów. Musi dążć do dojrzewania osobowości, zdolnej być „mostem, a nie przeszkodą dla innych w spotkaniu z Jezusem Chrystusem, Odkupicielem człowieka" (nr 1). Oznacza to „pozytywne poczucie swojej męskiej tożsamości i zdolność do dojrzałych relacji $z$ innymi ludźmi" ${ }^{\prime 5}$.

Każdy „formator” musi zatem być „dobrym znawcą osoby ludzkiej, jej wzrostem, jej możliwościami i słabościami” (n. 3), a przede wszystkim powinien „działać z rozeznaniem”, aby rozeznanie w czasie „nieudolności psychicznych, mniej lub bardziej patologicznych" pozwoliło „uniknąć wielu dramatów”56.

„Weryfikacja, nawet przy użyciu nauk medycznych $i$ psychologicznych, co do zdolności iprzydatności przyszlych kaptanów" (nr 11) jest prawem Kościoła (patrz kanon 1051 $\S 1$ ), która jednak musi być sprawowana przez wychowawców, formatorów i biskupa (patrz kanon 1052 § 1 i § 3), nie wplywając ani na prawo do dobrego imienia, ani na prawo każdej osoby do ochrony swojej prywatności, gwarantowane przez kan. 220 Kodeksu Prawa Kanonicznego z 1983 r.

\section{Wnioski i perspektywy}

Przede wszystkim: „Przygotowując się do kapłaństwa, musimy nauczyć się dawania osobistej odpowiedzi na podstawowe pytanie Chrystusa: «Czy miłujesz mnie?» (J 21, 15). Odpowiedzią przyszłego kapłana może być tylko calkowity dar wlasnego życia" 57 .

Ten „calkowity dar z siebie” oznacza „dojrzałość uczuciowa”, jako rezultat procesu formacyjnego „do prawdziwej i odpowiedzialnej miłości”, poprzez bycie rzeczywiście „zrównoważonymi, silnymi i wolnymi”, zdolnymi do przyjęcia „obowiązków duszpasterskich”, a zatem bycia „ludźmi jedności”

Ten „całkowity dar z siebie”, który jednocześnie stanowi istotę „celibatu kapłańskiego” i „miłości pasterskiej” jest faktycznie „misja miłości”, darem, który jest wyrazem Bożego Miłosierdzia, które „nie ma granic” i dokonuje się ostatecznie tylko w rzeczywistości życia wiecznego: w celibacie kapłańskim jak też i w dziewictwie „... człowiek pozostaje w oczekiwaniu, także cieleśnie, na zaślubiny eschatologiczne Chrystusa z Kościołem, ofiarując się całkowicie

$55 \quad$ Ibidem, s. 711.

56 Ibidem, nr 4, s. 713, gdzie dokument powtarza Wskazania wychowawcze dla formacji do celibatu kaptańskiego z 11.04.1974, nr 38 (por. EV, 5/725).

57 Jan Paweł II, Pastores dabo vobis, nr 42, akapit 4.

58 Ibidem, nr 43, akapity 3 i 4. 
Kościołowi w nadziei, że Chrystus odda się Kościołowi w pełni prawdy życia wiecznego" ${ }^{59}$. Innymi słowy,

celibat należy przyjąć z miłością, na podstawie wolnej i nieustannie odnawianej decyzji jako bezcenny dar Boga, jako bodziec miłości pasterskiej, jako szczególny udziat w ojcostwie Boga i w płodności Kościoła, jako świadczenie wobec świata o Królestwie eschatologicznym ${ }^{60}$.

Ten „całkowity dar z siebie” jest zatem tym samym, co ludzka dojrzałość powołanych do posługi kapłańskiej. Jan Paweł II w liście Novo incipiente, wysłanym do wszystkich kapłanów 8 kwietnia $1979^{61}$ r., wyraźnie pokazuje, że kapłan jest człowiekiem „wziętym z ludzi ... dla dobra ludzi” (Hbr 5,1), ale pokazuje także, a może przede wszystkim, iż szczególna "troska kapłana o ostateczne przeznaczenie każdego człowieka”, tradycyjnie zwana „troską o dusze” i nazwana przez św. Grzegorza Wielkiego „sztuką sztuki”, zakłada wyrzeczenie się małżeństwa dla Królestwa Niebieskiego, wyrzeczenie, które jest „raną”, która przywołuje tę „metafizyczną ranę” i pragnienie „mistycznego zjednoczenia" (tak centralne w doktrynie o wierze św. Jana od Krzyża!), pragnienie wpisane w serce każdego ochrzczonego, o którym mówi Katechizm Kościoła Katolickiego w numerze 2014.

Ten „całkowity dar z siebie”, jako wynik owocnego spotkania „łaski” z „wolnością” człowieka, wezwanym do bycia „pasterzem dusz” (OT 4,1), wskazuje także drogę, jaką nowi prezbiterzy muszą iść, aby osiągnąć „świętość na swój własny sposób" (PO 13,1), i w taki sposób, lub też poprzez wykonywanie posługi wypełnić, zobowiązanie każdego chrześcijanina do „prowadzenia świętego życia i przyczyniania się do wzrostu Kościoła i ustawicznego wspierania rozwoju jego świętości" (kanon 210).

Co więcej, jak przypomina nam w swojej autobiograficznej książce św. Jan Paweł II ${ }^{62}$ : „Trwałe owoce wysiłków duszpasterskich (i formacyjnych) wynikają ze świętości kapłana. To jest podstawa!”.

Słowa kluczowe: Wojtyła, Giussani, osoba ludzka, powołanie, wychowanie, formacja, młodzież.

\section{Bibliografia:}

1. AA.VV., Il Sicomoro. Un progetto che cresce, Como 2017.

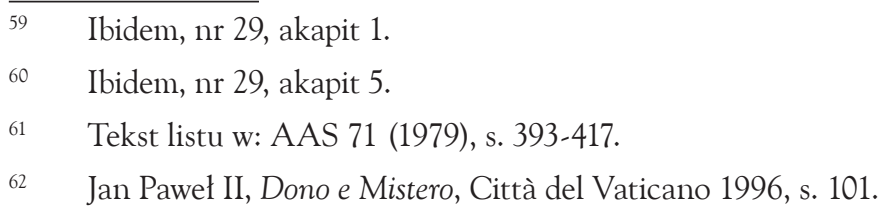


ks. Libero Gerosa, Wyzwanie zakorzenione w doświadczeniu edukacyjnym młodzieży...

2. Camisasca M., Don Giussani. La sua esperienza dell'uomo e di Dio, Cinisello Balsamo 2009.

3. Campagnaro M., La trasmissione della fede in una società secolarizzata sulla base degli scritti di Luigi Giussani, Varsavia 2016.

4. Di Corcia L., Liberi nella rete. Le dipendenze digitali, [w:] Ticino 7, nr 52, Lugano (CH) 29 grudnia 2017.

5. Gerosa L., Adduxit eum ad Iesum (J 1, 42). La formazione dei presbiteri o „pastori” secondo Giovanni Paolo II, [w:] Formare sacerdoti per il terzo millennio. Riflessioni a vent'anni dalla Pastores dabo vobis, M. Cardinali (red.), Città del Vaticano 2012, s. 49-70.

6. Gerosa L., Dove nasce l'uomo vero? Per un esercizio autentico della Misericordia, Lugano - Siena 2016.

7. Giussani L., Il rischio educativo, Milano 1977.

8. Giussani L., Realtà e giovinezza. La sfida, Milano 2018.

9. Giussani L., Tracce d'esperienza cristiana, [w:] L. Giussani, Il cammino al vero è un'esperienza, Milano 2016.

10. Giussani L., Tracce d'esperienza cristiana, [w:] L. Giussani, Il cammino al vero è un'esperienza, Milano 2016.

11. Jan od Krzyża, Żywy ptomień miłości, 3,30, [w:] Dzieła, Kraków 1998.

12. Jan Paweł II, Dono e Mistero, Città del Vaticano 1996.

13. Jan Paweł II, Encyklika Redemptor hominis (4 marca 1979), cytowana tu za: Jan Paweł II, Tutte le encicliche, red. R. Fisichella, Varese 2010.

14. Jan Paweł II, Esortazione Apostolica „Pastores dabo vobis”, nr 10, 25 marca 1992, [w:] AAS 84 (1992), s. 657-804.

15. Jan Paweł II, Lettera apostolica „Dilecti amici” per l'Anno internazionale della gioventù, 26 marca 1985, [w:] Insegnamenti di Giovanni Paolo II, t. VIII, 1 (Roma 1985), tekst łaciński s. 757-800 i tłum. wł. s. 801-837, tu akapit 3, s. 805.

16. Jan Paweł II, Lettera per la morte di Mons. Giussani, [w:] EV, t. 23 (Bologna 2008), s. 291-293.

17. Jan Paweł II, Omelia del 9 giugno 1987 all'Università Cattolica di Lublino, nr 2, [w:] Insegnamenti, Città del Vaticano 1987.

18. Jungmann J. A., Christus als Mittelpunkt religiöser Erziehung, Freiburg i. Br. 1939.

19. Kongregacja do spraw Kleru, Il dono della vocazione presbiteriale. Ratio Fundamentalis Institutionis Sacerdotalis, Milano 2016.

20. Papieska Rada do spraw świeckich, Decreto di riconoscimento della "Memores Domini", [w:] EV, t. 11 (Bologna 1991), s. 1014-1016.

21. Riccardi A., Giovanni Paolo II. La Biografia, Cinisello Balsamo 2011.

22. Tommaso D'Aquino, Quaestiones disputatae, "De veritate".

23. Wojtyła K., Experiences de nos grands séminaires: l'obéissance et l'esprit de dépendance, "Seminarium" n. 1 (1969), s. 79-87.

24. Wojtyła K., La sainteté sacerdotale comme carte d'identité, "Seminarium" n. 1 (1978), s. $167-181$. 